\title{
Population structure and reproductive biology of Cichla kelberi (Perciformes, Cichlidae) in Lobo Reservoir, Brazil
}

\author{
Jussara E. de Souza ${ }^{1}$, Evelise N. Fragoso-Moura², Nelsy Fenerich-Verani ${ }^{1}$, \\ Odete Rocha ${ }^{3}$ and José R. Verani ${ }^{1}$
}

The structure of Cichla kelberi population was characterized regarding the sex ratio, total length composition and some reproductive characteristics. The specimens were collected in two periods, from November 2002 to November 2003 and from December 2004 to May 2006. The sex ratio was significantly different than 1:1. The total length varied from 3.4 to $40.1 \mathrm{~cm}$, with individuals in the shortest length classes occurring throughout the year, but with greater incidence in the warmer periods. Females and males reached similar lengths and there was no difference between the sexes regarding the length-weight relationship. The estimated values of condition factor were near the central value of 1.0 and decreased during the cooler months, coinciding with periods of lower reproductive activity. Individuals with mature or semi-spent gonads occurred from November to April, indicating that Cichla kelberi reproduces for a long period of time. The spawning is partitioned, with an average absolute fecundity of 6072 oocytes (from 5220 to 6908 oocytes). The high relative condition factor values, long reproductive period, large output of fingerlings and high fecundity are biological conditions that indicate the species is well adapted in this reservoir.

A população de Cichla kelberi foi caracterizada quanto à proporção sexual, composição em comprimento total e algumas características reprodutivas. As coletas foram realizadas em dois períodos, de novembro de 2002 a novembro de 2003 e de dezembro de 2004 a maio de 2006. A proporção sexual foi significativamente diferente de 1:1. Os comprimentos totais variaram de 3,4 a 40,1 cm sendo que a ocorrência de indivíduos nas classes de menor comprimento se deu ao longo de todo o ano, com maior incidência nos períodos mais quentes. Fêmeas e machos atingem comprimentos similares e não houve diferença entre os sexos quanto à relação peso - comprimento. Os valores do fator de condição estimados foram próximos ao valor centralizador 1.0 e apresentaram quedas nos meses mais frios, coincidindo com períodos de menor atividade reprodutiva. Indivíduos com gônadas Maduras ou Semi Esgotadas ocorreram de setembro a abril, indicando que Cichla kelberi reproduz-se por um longo período. A desova é do tipo parcelada e apresenta, em média, uma fecundidade absoluta de 6072 ovócitos (de 5220 a 6908 ovócitos). Os altos valores de fator de condição relativo, longo período reprodutivo, grande produção de larvas e fecundidade alta são condições biológicas que indicam boa adaptação da espécie neste reservatório.

Key words: Condition factor, fecundity, length-weight relationship, reproduction.

\section{Introduction}

Technological advances have been expanding electricity demand. In Brazil, this has meant construction of more hydroelectricity power plants and the consequent formation of large reservoirs. These reservoirs alter various biotic and abiotic components of fluvial systems (Agostinho et al., 2005), such as changes in water flow, impeding the migration of many fish species within a watershed, or elimination of natural geographic barriers that

\footnotetext{
${ }^{1}$ Fish Population Dynamics Laboratory, Department of Hydrobiology, Federal University of São Carlos. Rodovia Washington Luiz, Km 235, 13.565-905 São Carlos, SP, Brazil. caju_jussara@yahoo.com.br (JES),dnfv@power.ufscar.br (NFV), verani@power.ufscar.br(JRV) ${ }^{2}$ Laboratory of Limnology, Department of General Biology, Federal University of Minas Gerais. Av. Antônio Carlos n.6627, Cx.Postal 486, 31.270-901 Belo Horizonte, MG, Brazil. evelise.fragoso@gmail.com

${ }^{3}$ Laboratory of Limnology, Department of Ecology and Evolutionary Biology, Federal University of São Carlos. Rodovia Washington Luiz, Km 235, 13.565-905 São Carlos, SP, Brazil. doro@power.ufscar.br
} 
prevent the passage of species between basins (Smith et al., 2005).

Another serious problem caused by dam construction is that the reservoirs, in an attempt to minimize impoverishment of the icthyofauna, are generally stocked with fish, but often with non-native species. In Brazil these species were widely used in stocking until the 1980s, under the recommendation of the very entities responsible for conservation of water resources (Agostinho et al., 2005).

The introduction of non-native species is the second greatest cause of extinction of species, surpassed only by degradation of habitats (Simberloff, 2003). Besides the local extinction of native species, the introduction of exotic or alochtone species are responsible for other impacts, such as changes in the trophic webs and population balance of the communities and alterations in the functional processes of ecosystems (Rocha et al., 2005). These changes occur due to the competition for food and space between native and introduced species, predation of native species, introduction of new pathogens and parasites, possible hybridization between proximate species (Rocha et al., 2005) and invasion of areas of high endemism (Smith et al., 2005).

Some works have evaluated the effects of introducing of Cichla sp. in native communities. In Panama, the dispersion of Cichla ocellaris in the area of the Chagres River led to the disappearance of many native fish species, as well as zooplankton, insects and piscivorous birds, simplifying the food chain (Zaret \& Paine, 1973). Godinho et al. (1994), comparing the icthyofauna of the lakes in the Rio Doce Valley in Minas Gerais, Brazil, reported that small fish species disappeared from lakes colonized by Cichla ocellaris.

The species of the genus Cichla, popularly called tucunaré in Brazil, are piscivores that are adapted to lentic environments. Due to the quality of their flesh and characteristics as a game fish, they have been introduced and become established in various Brazilian watersheds (Magalhães et al., 1996; Nascimento et al., 2001; Câmara et al., 2002; Chellapa et al., 2003; Gomiero \& Braga, 2003).

Cichla kelberi has only been described recently. It stands out from the two most similar species (C. monoculus and $C$. pleiozona) by the presence in adults of small light spots on the pelvic and anal fins and lower lobe of the caudal fin. It has three dark vertical bars on the body side, and there is a pronounced occipital bar in large specimens and irregular dark blotches on the anterior abdominal side. It has 76-83 scales in the row above that containing the lower lateral line, this number of scales is larger than in C. monoculus and smaller than in C. pleiozona (Kullander \& Ferreira, 2006).

The species' original geographic distribution is the basin of the Araguaia and lower Tocantins rivers. Currently it is also found in reservoirs in the states of Rio Grande do Norte, Ceará, Minas Gerais and in the Paraná River, as a result of translocations (Kullander \& Ferreira, 2006). This species until now was known as and confused with Cichla monoculus (Kullander \& Ferreira, 2006).

Studies of the reproduction of Cichla sp. by Fontenele
(1950), Magalhães et al. (1996), Câmara et al. (2002), Chellapa et al. (2003), Gomiero \& Braga (2004) and Souza et al. (2005) report that the species of this genus have an elaborate reproductive process. Fontenele (1950) observed the mating behavior, formation of nests and parental care by both sexes. The eggs are adhesive and after hatching the larvae attach themselves to the substrate by means of adhesive organs. During the spawning period, the males present sexual dimorphism, developing a post-occipital protuberance formed by an accumulation of adipose tissue.

In Lobo (also called Broa) Reservoir, according to subsistence fishermen and nearby residents, the tucunaré was introduced in later 1990s, probably by release and consequent escape from handling fish farming tanks in the region (Marinelli, 2002).

The objectives of this work were to analyze the population structure and reproductive characteristics of Cichla kelberi in Lobo Reservoir, to evaluate the current adaptive condition of the species in this environment.

\section{Material and Methods}

Description of the area. Lobo Reservoir lies within the municipalities of Brotas and Itirapina in São Paulo State. It is located at $22^{\circ} 15^{\prime}$ 'S and $47^{\circ} 40^{\prime} \mathrm{W}$ (Fig. 1). The dam was built in 1936 for power generation, and the reservoir is nowadays also used for fishing, recreation and scientific research (Tundisi et al., 2003). Other activities in the watershed are sand mining, agriculture, stock raising on pasture and reforestation (Tundisi et al., 2003). The reservoir is formed mainly by the damming of the Itaqueri river and Lobo stream, and has been undergoing eutrophication, caused mainly by domestic sewage from the town of Itirapina, discharged, after sedimentation, in one of the reservoir's affluents (Tundisi et al., 2003).

The surrounding vegetation is predominantly Cerrado,

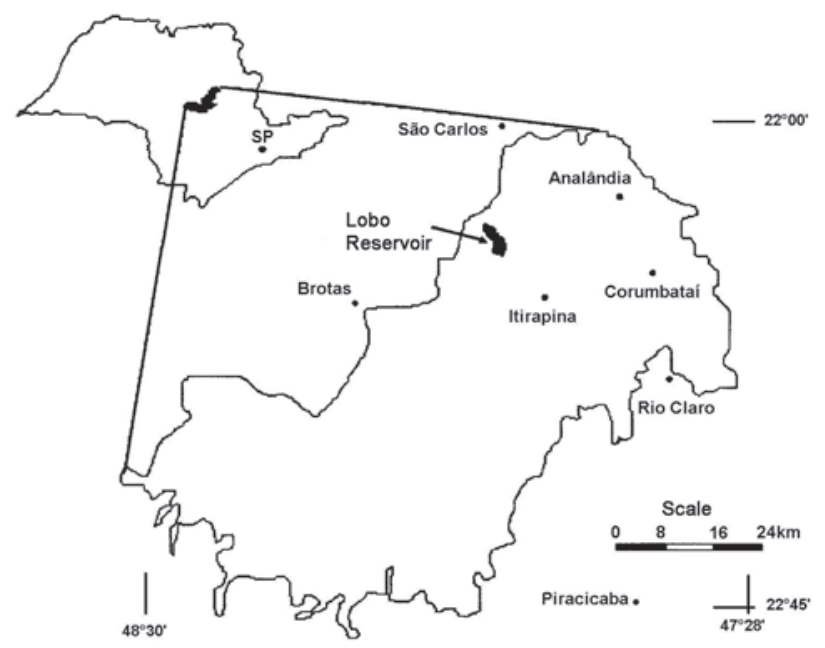

Fig. 1. Map showing the location of Lobo Reservoir in the Corumbataí/Botucatu/Tejupá APA, São Paulo State. (Source: Marinelli, 2002). 
with stands of riparian forest and areas reforested with Pinus sp. and Eucalyptus sp. The region's climate is characterized by wet springs and summers and dry autumns and winters (Tundisi et al., 2003).

Lobo Reservoir is located in an area of great interest for conservation, the Corumbataí/Botucatu/Tejupá Environmental Protection Area (APA), created by State Decree 20,960, issued on June 8, 1983. This APA is divided into three distinct perimeters, with the Corumbataí perimeter including 13 municipalities besides those of Itirapina and Brotas, with an area of 272,692.09 hectares (Fragoso, 2005).

Sampling. The abiotic characterization of the environment was done by temperature and rainfall data obtained from the Weather Station of the Center for Water Resources and Applied Ecology of São Paulo University - São Carlos (CRHEA-USP), located on the shore of the reservoir.

To characterize the population, the fishes were collected in two periods. The first started in November 2002, to determine the best sampling points, and then monthly from January to November 2003, with three batteries of gill nets with meshes of 3, 4, 6, 8, 10 and $12 \mathrm{~cm}$ between opposite knots, which remained submersed for approximately 12 hours during the night. To capture smaller specimens, from January 2003 collections in shallow regions were done using a seine net with $1.0 \mathrm{~cm}$ mesh in the early morning and evening. Because of the large number of tucunaré specimens caught in the seine net, it was divided into classes according to total length by the Sturges method (Silva \& Souza, 1987), and then sub-sampled.

Information from fishermen in the region was important to clarify the occurrence of individuals of greater length compared with the specimens collected in the first period. To complement the initial data with larger fish, it was decided to acquire samples from professional fishermen, according to availability, considering a second sampling period running from December 2004 to May 2006. The fishermen used gill nets placed in the water at dusk and retrieved the next morning three times in week. In some months there were no fishes collected from the fishermen.

The specimens were conserved on ice and taken to the Fish Population Dynamics Laboratory of São Carlos Federal University, where the total and standard lengths were recorded in centimeters and the body weight in grams. During dissection the gonads were removed, weighed and evaluated regarding to sex and their state of maturity, based on the coloration, volume occupied in the visceral cavity, surface blood supply, and in the ovaries, presence and size of the visible oocytes. The gonads were fixed in Bouin's fluid, embedded in paraffin, sectioned to a thickness of $5 \mathrm{~mm}$ and stained with hematoxylin and eosin, as described in Vazzoler (1981), for subsequent analysis under a light microscope and confirmation of the state of gonad maturity.

The specimens were identified at the species level based on the work of Kullander \& Ferreira (2006), and one lot, containing representative exemplars of all the length classes, were deposited in the collection of the Zoology Museum of the University of São Paulo (MZUSP 93245).

Data analysis. To analyze the population composition according to sex, the two collection periods were divided into two-month intervals and the specimens into total length classes of $3 \mathrm{~cm}$. To the frequency of males and females in theses classes was applied the Chi-square test (Vieira, 1980) to check for a possible difference in relation to the theoretical $1: 1$ sex ratio $\left(H_{0}=\right.$ the male-female sex ratio is $\left.1: 1\right)$.

The analysis of population structure in relation to total length, was made by establishing classes with amplitude of 3 $\mathrm{cm}$ and analyzed the frequencies in these classes seasonally: spring (September, October and November), summer (December, January and February), autumn (March, April and May) and winter (June, July and August), grouping the two collection periods .

To determine the length- weight relationship, applying the methodology proposed by Le Cren (1951), the weight and total length variables were plotting on graphs to investigate the tendency of the empirical points and fitting the curve by the expression $\mathrm{Wt}=\mathrm{a} \mathrm{Lt}^{\mathrm{b}}$, where $\mathrm{Wt}=$ total weight, $\mathrm{Lt}=$ total length, $\mathrm{a}=$ intercept and $\mathrm{b}=$ isometry coefficient. The values of $a$ and $b$ were estimated by $\log$ transformation of the values of Wt and Lt and then the best linear fit was found by least squares (Santos, 1978).

To complement the analysis of the length-weight relationship, the individual variations of this relationship, expressed by the relative condition factor were estimated. This factor (Kn) was estimated by the equation $\mathrm{Kn}=\mathrm{Wt} /$ $\mathrm{We}$, where $\mathrm{Wt}=$ total weight and $\mathrm{We}=$ expected theoretical weight estimated by the length-weight relationship. The values estimated of $\mathrm{Kn}$ of adults males and females for the two periods of collection were grouped monthly and the mean values were compared to the central value $(\mathrm{Kn}=1.0)$ by Student's t-test (Vieira, 1980) at 95\% confidence.

The reproductive aspects of the Cichla kelberi population characterized in this work were size at first gonad maturation, reproductive period, type of spawning and fecundity.

The size at first maturation was estimated using the method proposed by Sato \& Godinho (1988), which considers the size at first maturation as being the shortest length at which individuals at advanced maturation occur.

The reproductive period was determined by grouping the two periods of collection and analyzed, only for adults individuals, the frequency of occurrence of individuals with mature gonads as well as the monthly variation of gonadosomatic index (GSI=Wg/Wt*100) mean values. The spawning type was inferred by histological inspection of ovaries.

Females with mature gonads collected in the second period had the ovaries disassociated in a modified Gilson solution (Vazzoler, 1981; 1996) to estimate the fecundity (number of vitellogenic oocytes per ovary), by the volumetric method described in Vazzoler (1981; 1996). 


\section{Results}

Abiotic factors. The region where Lobo Reservoir is located has two distinct seasons. The high temperatures and rainfall occurred from September to April and low temperatures and rainfall from May to August. The highest average air temperature was $25.1^{\circ} \mathrm{C}$ and was reached in the first period of collection, in January-February and March-April 2003. The maximum rainfall reached $611.3 \mathrm{~mm}$, during the second period of collection, in January-February 2005. The average bimonthly values of air temperature and rainfall are presented in Figure 2.

Grouping both periods, the mean values of air temperature and rainfall were $22.5^{\circ} \mathrm{C}$ and $97.5 \mathrm{~mm}$ in the spring, $24.0^{\circ} \mathrm{C}$ and $223.7 \mathrm{~mm}$ in the summer, $21.8^{\circ} \mathrm{C}$ and $55.4 \mathrm{~mm}$ in the autumn and $18.3^{\circ} \mathrm{C}$ and $16.9 \mathrm{~mm}$ in the winter.

Population composition. Sex ratio. During the study it was collected 484 specimens of Cichla kelberi, of which 380 were collected in the first period and 104 in the second. In the first period it was possible to identify the sex of 234 females and 91 males, resting 55 not identified, while in the second the sex of all the fish was determined, with 47 being females and 57 males. There was a significant difference in the sex ratio (1:1) of the total individuals captured $\left(X^{2}=41.23, \mathrm{df}=1, \mathrm{p}<0.05\right)$, with females predominating during the entire first period except in November of 2002 and November of 2003. In the second period, the male-female ratio was near 1:1.

By analyzing the sex ratio in the different length classes (Fig. 3), the null hypothesis was rejected in the smaller length classes, from 3.4 to $15.4 \mathrm{~cm}$, with predominance of females. In the classes longer than $15.4 \mathrm{~cm}$, there was a small difference in the sex ratio only in the class from 24.4 to $27.4 \mathrm{~cm}$, with males predominating. In the other classes, this difference was not found.

Structure according to total length. The total length varied from 3.4 to $40.1 \mathrm{~cm}$, distributed into 13 classes with amplitude of $3 \mathrm{~cm}$ (Fig. 4). The individuals in the smaller length classes made up the large majority in the summer and autumm. The largest specimen was a male collected in May of 2005, measuring $40.1 \mathrm{~cm}$ in total length and weighing $992.8 \mathrm{~g}$.

Length-weight relationship and condition factor. After establishing the linear relation between the logarithms of the variables Wt and Lt, the length-weight relationship was obtained for the females and males. Since these practically overlapped, it was considered a single relationship: $\mathrm{Wt}=$ $0.007623 \times$ Lt $^{3.1747}$

The average values of the relative condition factor $(\mathrm{Kn})$ were $1.0092( \pm 0.0537)$ and $1.0029( \pm 0.0632)$ for females and males, respectively. In the first period, the mean relative condition factor was $1.0013( \pm 0.1121)$ for females and 1.0005 $( \pm 0.1476$ ) for males, and in the second period it was 1.0125 ( \pm $0.1253)$ for females and $1.0293( \pm 0.0780)$ for males.

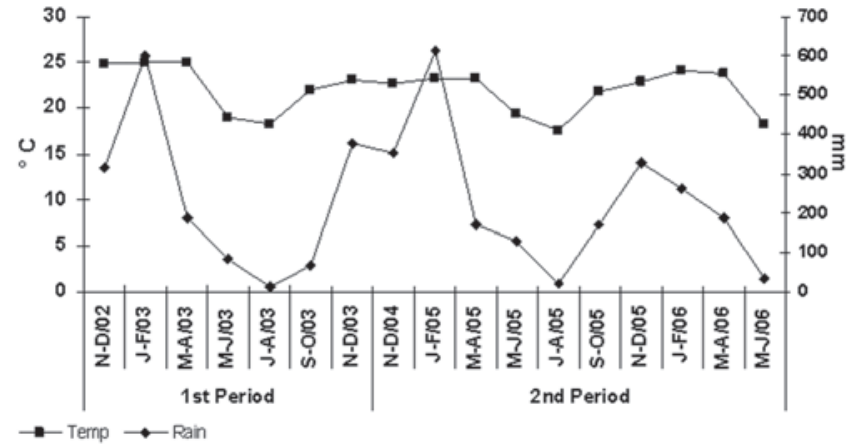

Fig. 2. Bimonthly variation of average air temperature $\left({ }^{\circ} \mathrm{C}\right)$ and total rainfall (mm) at Lobo Reservoir during the first and second period of study.

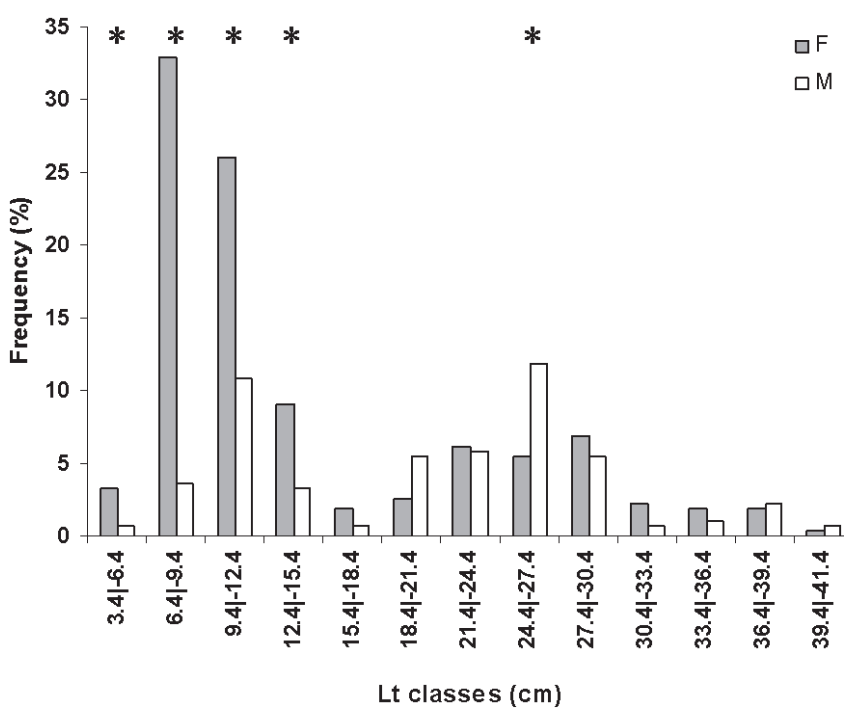

Fig. 3. Distribution of the absolute frequencies of occurrence of females and males of Cichla kelberi in the total length classes - Lt - (cm) in Lobo Reservoir during the study period. (Legend: * sex ratio different than 1:1).

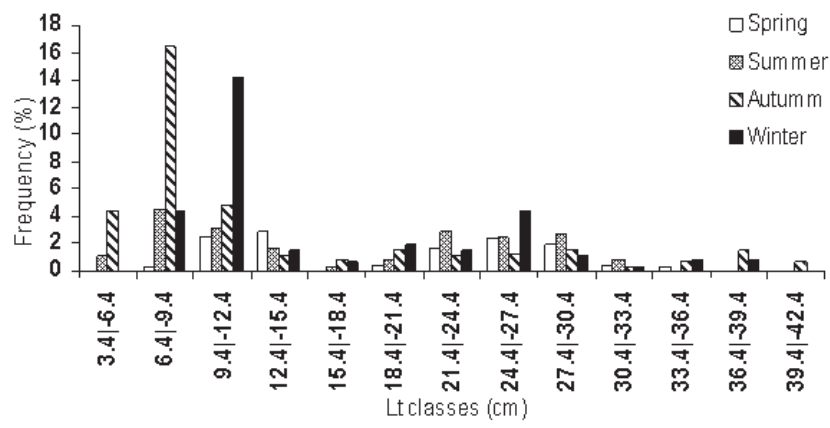

Fig. 4. Distribution of the relative frequencies of occurrence of specimens of Cichla kelberi in total length classes, by seasons of the year, at Lobo Reservoir. 
Analyzing the mean values of Kn only for adults (the ones with a higher Lt than the size of first maturation) on both periods, higher values may be observed for females during April, June and December and lower values during March, May and July. For males, the higher mean values of Kn occurred in April, May, July and August and lower values in June.

Based on the t-test for comparing the relative condition factor values obtained in this work and the central value 1.0, the null hypothesis $\mathrm{H}_{0}: \mathrm{Kn}=1.0$ was rejected for females in the months of January, June and December. For the males the null hypothesis $\mathrm{H}_{0}: \mathrm{Kn}=1.0$ was rejected in March, May and September. Figure 5 shows the average estimated of Kn of adult individuals for the entire study, grouped monthly and the months where Kn differed significantly from the central value of 1.0 .

Reproduction. The size at first maturation estimated for Cichla kelberi in Lobo Reservoir for females and males was 20.7 and $21.5 \mathrm{~cm}$ in total length, respectively.

Regarding the gonad maturity states, after analyzing the slides of testicle and ovary tissue under the microscope, individuals were classified as: 1 - Resting; 2 In Maturation; 3 - Spawning (including semi-spent); and 4 - Spent. Adults males and females in the Resting stage were numerous during July and, specially, in August. In Maturation and Spawning individuals occurred from November to April and in the Spent stage occurred predominantly from May to August, but also occurred simultaneously to In Maturation individuals (Fig. 6).

Besides this, the microscopic analysis of gonads of In Maturation and Spawning individuals showed group synchronous development of oocytes and spermatocytes, as well as the presence, in ovaries, of post-ovulatory follicles, indicating partitioned spawning (Fig 7).

The gonadosomatic index (GSI) values of adults of Cichla kelberi females varied from 0.0087 to 4.7433 during the study, and the GSI values of adults males ranged from 0.0044 to 0.8392 . The higher mean values of female GSI occurred in December and April, periods in which the higher individual values were also registered. For males, the higher mean values were registered in November, December, January, April and June. The value presented in June is relative only one male captured. Higher individual values were registered in November and January. Figure 8 presents females and males monthly variations from the mean GSI.

To estimate the absolute fecundity were considered the vitellogenic oocytes , that is, those measuring from 1,505 ìm to $2,485 \mathrm{ìm}$, ready to be eliminated during spawning. The absolute fecundity values estimated for two mature females were 6,089 and 6,908 oocytes. The number of vitellogenic oocytes of one semi-spent female totaled 5,220 oocytes. The estimated fecundity values along with those for GSI and total length of the females analyzed are shown in Table 1.
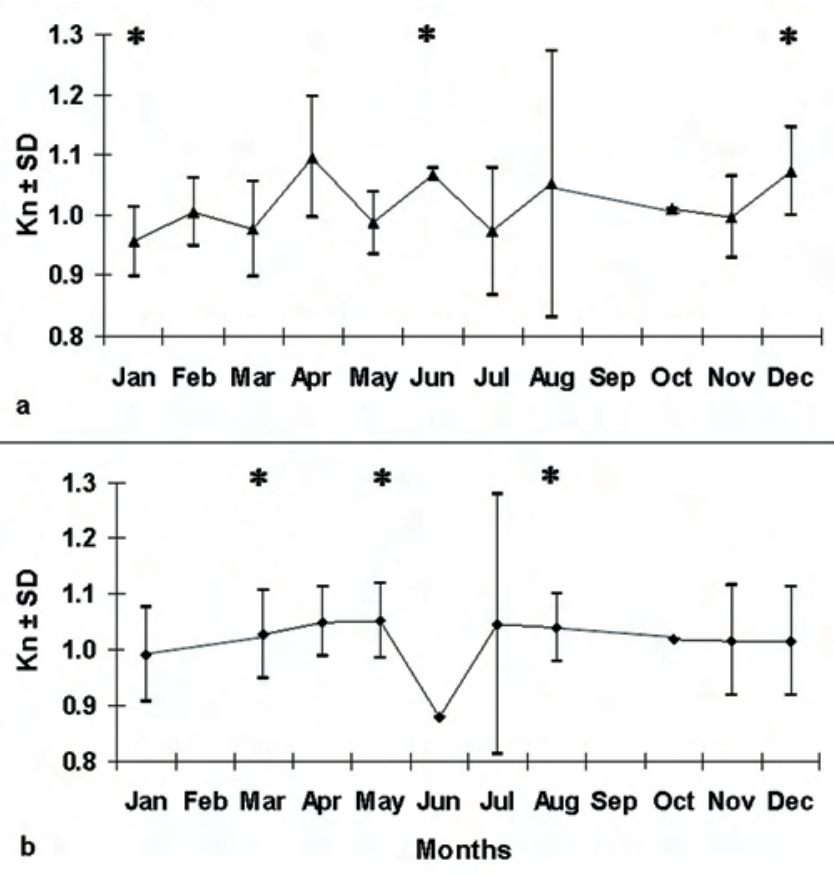

Fig. 5. Monthly variation of the mean relative condition factor values (Kn) \pm Standard Deviation (SD) of Cichla kelberi females (a) and males (b), in Lobo Reservoir, during the study period. (Legend: * Kn of significantly different than 1.0).

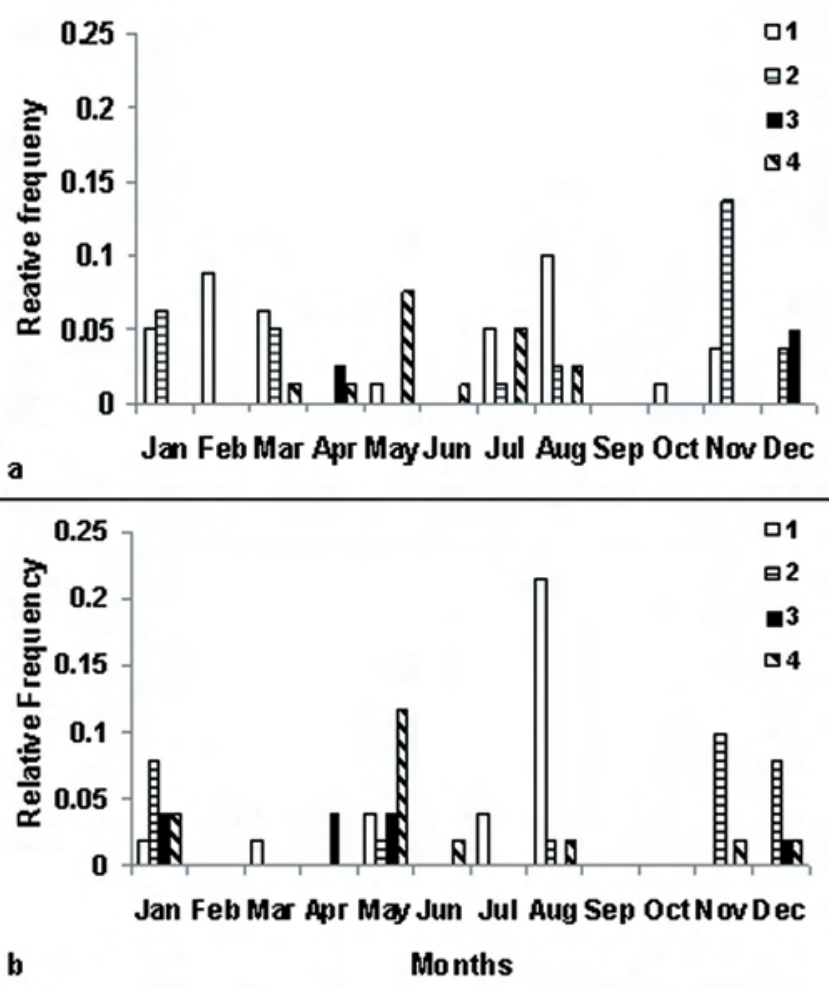

Fig. 6. Monthly distribution of frequency of gonadal maturation stages of females (a) and males (b) of Cichla kelberi in the Lobo reservoir during the study. (Legend: 1Resting; 2- In Maturation; 3- Spawning and 4- Spent). 

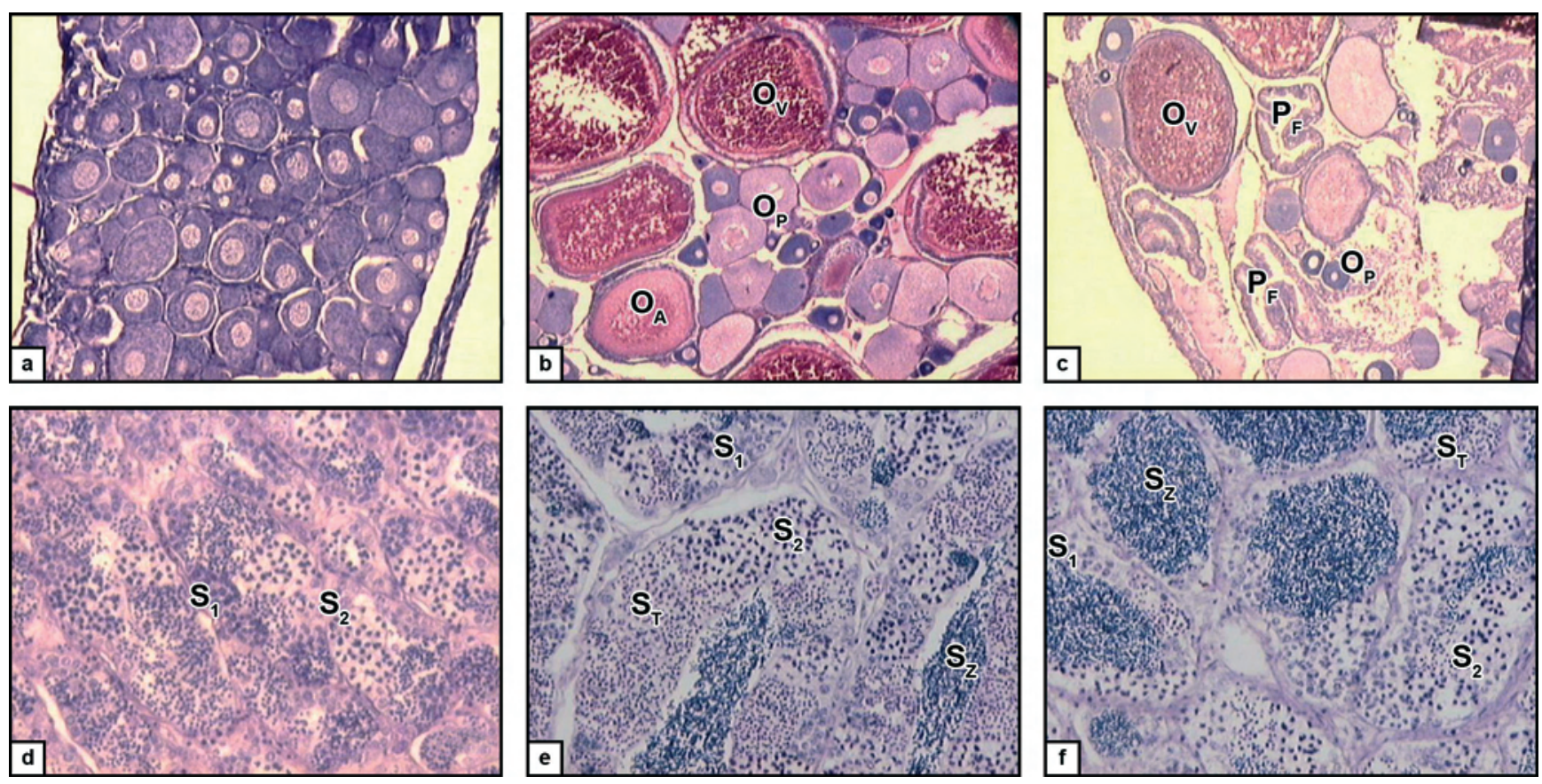

Fig. 7. Histological slides of gônads of Cichla kelberi female $(a-c)$ and male $(d-f)$ in Lobo reservoir (Bouin, hematoxylin and eosin). a- Resting ovary with perinucleolar oocytes (100x); b- In Maturation ovary showing group synchronous development of oocytes (40x); c- Spent ovary with post-ovulatory follicles (40x); d- Resting testicle (200x); e and f- In Maturation testicle showing group synchronous development of spermatocytes (200x). Legend: $\mathrm{O}_{\mathrm{P}}$ : perinucleolar oocyte, $\mathrm{O}_{\mathrm{A}}$ : cortical alveoli oocyte, $\mathrm{O}_{\mathrm{V}}$ : vitellogenic oocyte, $\mathrm{P}_{\mathrm{F}}$ : post-ovulatory follicle, $\mathrm{S}_{1}$ : primary spermatocyte , $\mathrm{S}_{2}$ : secondary spermatocyte, $\mathrm{S}_{\mathrm{T}}$ : spermatid and $\mathrm{S}_{\mathrm{Z}}$ : spermatozoid.
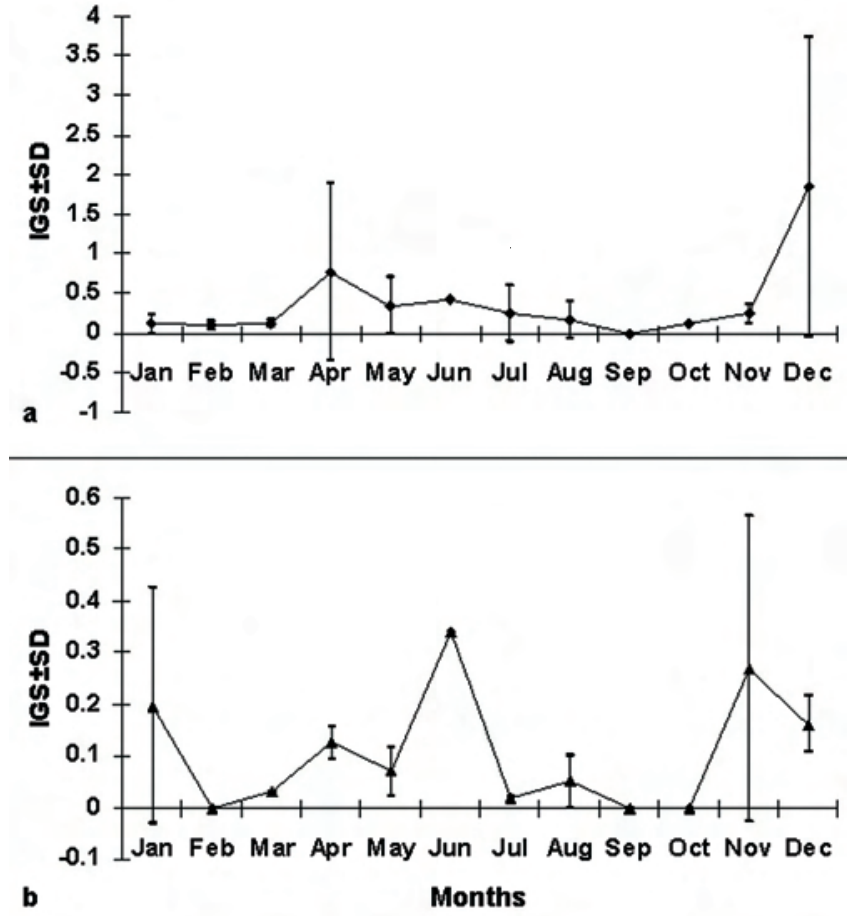

Fig. 8. Monthly variation of the mean values of GSI \pm Standard Deviation (SD) of Cichla kelberi females (a) and males (b), in Lobo Reservoir, during the study period.
Table 1. Absolute fecundity estimated for females "in reproduction" of Cichla kelberi and oocyte counts of semispent females in Lobo Reservoir during the study period, compared to the GSI and total length. (* Variables and parameters estimated for semi-spent females).

\begin{tabular}{llll}
\hline $\begin{array}{l}\text { Total Length } \\
(\mathrm{cm})\end{array}$ & GSI & $\begin{array}{l}\text { Number of Oocytes } \\
\text { per Ovary }\end{array}$ & $\begin{array}{l}\text { Number of } \\
\text { Vitellogenic Oocytes }\end{array}$ \\
\hline 29.8 & 4.743 & 29.336 & 6.089 \\
35.2 & 2.069 & 17.550 & 6.908 \\
$30.2^{*}$ & 3.302 & 29.160 & 5.220 \\
\hline
\end{tabular}

\section{Discussion}

The sex ratio can vary temporarily, resulting in changes in the structure of fish populations, as a result of successive events that affect males and females differently, such as mortality and growth (Vazzoler, 1996). Besides these events that can affect the sexes differently, another factor that interferes in the sex ratio and the length distribution of the population samples is the selectivity of the capture method.

In the present study, the sex ratio differed from 1:1, with predominance of females on length classes smaller than 15.4 $\mathrm{cm}$. This difference could be due to the greater facility of distinguishing female gonads, however, when comparing the number of females on smaller length classes and the number of males summed to the number of individuals undifferentiated 
on the same length classes, there is still a predominance of females, suggesting that this difference may be related to other factors.

Considering that the smaller length individuals were collected, in its majority, with the seine net - a less selective device regarding size and/or sex - it is possible that the difference not detected in the classes of higher length is related to the small number of individuals captured in those classes (those were captured in the gill net which is more selective).

Câmara et al. (2002) and Chellapa et al. (2003) found a sex ratio near $1: 1$, with a slightly predominance of females amongst the larger individuals (length higher than $17.8 \mathrm{~cm}$ ).

In Lobo Reservoir, Cichla kelberi males and females reach similar maximum lengths. The same observation has been made in some other places where Cichla species have been studied (Jepsen et al., 1999; Câmara et al., 2002; Chellapa et al., 2003). In Volta Grande Reservoir in Minas Gerais, C. monoculus males and females attained similar lengths, while $C$. ocellaris males were larger than the females (Gomiero \& Braga, 2003).

In the present study, the maximum lengths recorded were near those found in studies of species of the genus Cichla in other Brazilian watersheds where they have been introduced (Câmara et al., 2002; Chellapa et al., 2003; Gomiero \& Braga, 2003), but smaller than those recorded in studies conducted in the basins of origin (Winemiller et al., 1997; Jepsen et al., 1999).

A single species can reach different maximum lengths depending on the environment where it is established. Winemiller et al. (1997) studying three species of Cichla in two rivers in Venezuela, demonstrated the influence of ecological factors, such as food availability and environmental characteristics, in the length structure of C. temensis populations.

Individuals smaller than $3.4 \mathrm{~cm}$ are not normally captured, because one of the characteristics of this species is parental care, by both parents, until the brood reaches approximately $3.5 \mathrm{~cm}$ in length, before when the fingerlings stay close to their parents (Fontenele, 1950).

In the present study, the greater incidence of individuals within the smaller length classes occurred during the autumn and winter of 2003 (classes $6.4 \% 9.4 \mathrm{~cm}$ and $9.4 \% 12.4 \mathrm{~cm}$, respectively) possibly resulting from a period of greater reproductive activity, considered a a reproductive peak, in the preceding months starting in the beginning of the summer, as well as the capture effort and collection method.

The length-weight relationship can offer important information about a population because it describes structural characteristics of the individuals within the population (Le Cren, 1951; Barros et al., 2001). This relationship did not differ between males and females in the present study. According to Zaret (1980), Cichla ocellaris females and males showed similar growth rates until one year of age, after which males developed more than females, possibly due to the energy spent by females in producing eggs.

In the length-weight relationship, the coefficient $b$ is considered a measure of relative growth, also reflecting the recent food conditions (Le Cren, 1951). The b value was near those estimated in other works for species of Cichla (Winemiller et al., 1997; Jepsen et al., 1999; Gomiero \& Braga, 2003; Hoeinghaus et al., 2006). The growth rate, and consequently the coefficient of relative growth (b) of the length-weight relationship, is generally higher in places where Cichla were recently introduced (Zaret, 1980). According to this author, the reason to this is that soon after the introduction, the absence of predators and the large supply of prey makes the growth increase at first, after which the relationship tends to decline due to predation and competition.

The condition factor is related to various aspects, such as cyclical changes in the gonad development, growth and accumulation of fat, stomach repletion and environmental variations (Barbieri \& Verani, 1987). Some environmental influences can lead to errors in interpreting the condition, such as availability of food, parasites and unfavorable environmental conditions (Le Cren, 1951).

The estimated values of the relative condition factor (Kn) were near 1.0, indicating that the Cichla kelberi population is doing well in the reservoir studied. This variable was significantly different than 1.0 for adults females and males in some months as a consequence of low temperature and the reproductive status. Low values of Kn estimated to the period between July and September may be related with the post reproduction phase or to the reduction during the winter of metabolic activity and the resulting decline of feeding activity specially by being an introduced species from warmer regions.

In some months the differences of the Kn values for females and males may be related to the smaller number of individuals captured, such as in April, June and October.

Studies of species of the Cichla genus also report smaller values of Kn in fish just after spawning (Câmara et al., 2002; Gomiero \& Braga, 2003). In periods after reproductive activity, the values of Kn can be lower, not only because of the energy investment in gonad development (which is released to the environment during spawning), but also by the fact that the fish interrupt their feeding activity while caring for their brood (Zaret, 1980).

The size at first maturation for Cichla kelberi in Lobo Reservoir is smaller than the estimates by other authors for other Cichla species. According to Zaret (1980), in Gatun Lake, Panama, C. ocellaris females and males start the reproductive process with standard lengths of 32.2 and 33.2 $\mathrm{cm}$, respectively. In the Brazilian Northeast, in Campo Grande Reservoir in Rio Grande do Norte state, Câmara et al. (2002) estimated a total length at first maturation for C. monoculus of $21.4 \mathrm{~cm}$ for females and $32.2 \mathrm{~cm}$ for males. In the Southeast region, in the Volta Grande Reservoir in Minas Gerais, females and males of two species of tucunaré are able to reproduce when they reach similar lengths (Gomiero \& Braga, 2004). These authors estimated the total length at first maturity for C. ocellaris and C. monoculus of 20.0 and $21.5 \mathrm{~cm}$, respectively.

The differences in size at first maturation can be attributed to various factors, such as species differences, methods of 
determining the size at first maturation or an adaptation of the species to Lobo Reservoir, which is located in a region influenced by seasonal variations.

Câmara et al. (2002) and Gomiero \& Braga (2004) used a method described by Vazzoler (1996), to determine the size at first maturation, which assumes the length in which $50 \%$ of the individuals presents developing gonads. However, this method could not be used in this study due to the low occurrence of individuals in the length classes that define the size at first maturation.

Criteria based upon histological analysis are useful to estimate the size of the first maturation because of its accuracy in identify youngsters and adults. Furthermore, identification of the maturity state done only based on external morphological characteristics has not shown itself to be very efficient (particularly in species with multiple spawning). Histological analyses are strongly recommended because often the changes observed macroscopically do not exactly reflect the biological events during the reproductive process (Honji et al., 2006).

The differences in size at first maturation can also be related to external factors. In Lobo Reservoir juveniles experience a period of low temperatures in the winter, that can retard growth. This pressure does not occur in places where the temperature variations are smaller, such as the Brazilian Northeast, where after completing one year of life, the age of first maturity of Cichla ocellaris (Zaret, 1980), the individuals have reached greater lengths.

The greater frequency of In Mautration and/or Spawning gonads occurred during periods of higher temperatures and rainfall, coinciding also with higher GSI values. Individuals with Spent gonads had lower GSI and occurred specially in periods where temperature and rainfall start to drop, coinciding with end of autumn and beginning of winter. In the end of winter and beginning of spring there was greater incidence of Resting gonads.

The mean GSI values of adults in this study were near those found in other works on reproduction of species of this genus (Câmara et al., 2002; Chellapa et al., 2003). It was recorded higher GSI values for females than males, indicating that the former make a greater investment in gametes production during spawning.

Individuals of Cichla kelberi in Lobo reservoir had mature and semi-spent gonads from November to April, indicating a long reproductive period. However, there was an activity peak, as mentioned previously. Long reproductive periods with activity peaks have been reported for other species of Cichla. Magalhães et al. (1996), studying C. ocellaris in Três Marias Reservoir, found that these fish reproduce throughout the year, with activity peaks in the period when the water level behind the dam starts to rise.

Chellapa et al. (2003) studied the reproductive ecology of Cichla monoculus in Campo Grande Reservoir (Brazilian Northeast) and found that in this environment, tucunaré reproduce for a long period, with peak activity coinciding with lower water temperature (approximately $27^{\circ} \mathrm{C}$ ).
According to Zaret (1980), fecundity is related to the female's length and can present wide variation. The mean absolute fecundity of Cichla kelberi females in Lobo Reservoir was near that observed by Fontanelle (1950) and Câmara et al. (2002), but substantially below that reported by Gomiero \& Braga (2004). The vitellogenic oocytes of the Cichla species have large diameters (2,400 mm), supplying a large store of energy in the form of vitellum for the recently hatched larvae.

Partitioned spawning stretching over a prolonged period reduces the competition among larvae, and afterward among the fingerlings. This type of spawning has previously been reported for species of Cichla (Fontanelle, 1950; Magalhães et al., 1996; Câmara et al., 2002; Gomiero \& Braga, 2004).

Large oocyte diameter, parental care of the brood and partitioned spawning constitute a strategy that favors reproductive success. The reason is that the large reserve of vitellus in the oocytes permits larger and more developed larvae to hatch, which are then defended from predators by their parents, thus ensuring a higher survival rate.

The reproductive biology characteristics of $C$. kelberi in Lobo Reservoir indicate that the species is well adapted to its environment, with high relative condition factor values, a long reproductive period, large output of fingerlings and fecundity values near those of other populations established for longer periods. In this environment the maximum sizes are near those in other regions where these species occur and the size at first maturation is smaller for both sexes, probably because of adaptation to local environmental conditions such as periods of lower temperatures, which cause a reduction in the growth rate.

Previous studies of the icthyofauna in Lobo Reservoir demonstrate that after $C$. kelberi was introduced, at the end of the 1990s, there was a change in the communities, with a decline in the relative abundance of some species, such as Hoplias malabaricus, Geophagus brasiliensis, Astyanax fasciatus, Cyphocharax modestus and Gymnotus carapo, and an increase in the relative abundance of the tucunaré (Fragoso et al., 2005). It is important to stress that once established, it is extremely difficult to eradicate a species (Lowe-McConnell, 1999). So the implementation of efficient mechanisms to control this species is necessary to minimize its potentially harmful effect on the aquatic community.

\section{Acknowledgments}

We thank the Brazilian Ministry of Environment (MMA) and co-sponsors of the PROBIO Project for funding this research and to CAPES for the Master Scholarship awarded to the first author.

\section{Literature Cited}

Agostinho, A. A., F. M. Pelicice \& H. F. Júlio Jr. 2005. Introdução de espécies de peixes em águas continentais brasileiras: uma 
síntese. Pp. 11-23. In: Rocha, O. (Ed.). Espécies invasoras em águas doces - estudo de caso e propostas de manejo. São Carlos, Editora Universidade Federal de São Carlos, 416p.

Barbieri, G. \& J. R. Verani. 1987. O fator de condição como indicador do período de desova em Hypostomus aff. plecostomus (Linnaeus, 1758) (Osteichthyes, Loricariidae), na represa do Monjolinho (São Carlos, SP). Cultura e Ciência, 39(7): 655-658.

Barros, S. E., S. G. Mosa, H. A. Regidor \& S. S. Sühring. 2001. Relaciones longitud - peso em peces del embalse Cabra Corral, Salta, Argentina. Boletín de la Sociedad de Biología de Concepción, 72: 25-30.

Câmara, M. R., N. T. Chellappa \& S. Chellappa. 2002. Ecologia reprodutiva do Cichla monoculus, um ciclídeo amazônico no semi-árido do Rio Grande do Norte. Acta Limnologica Brasiliensia, 14(2): 9-16.

Chellapa, S., M. R. Câmara \& N. T. Chellapa. 2003. Ecology of Cichla monoculus (Osteichthyes: Cichlidae) from a reservoir in the semi - arid region of Brazil. Hydrobiologia, 504: 267-273.

Fontenele, O. 1950. Contribuição para o conhecimento da biologia dos tucunarés (Actinopterygii, Cichlidae), em cativeiro. Aparelho reprodutor. Hábitos de desova e incubação. Revista Brasileira de Biologia, 10(4): 503-519.

Fragoso, E.N. 2005. Ictiofauna da microbacia do córrego da Lapa, bacia do Alto Paraná, Itirapina/Ipeúna, SP. Unpublished Ph.D. Dissertation, Universidade Federal de São Carlos, São Carlos. 130p.

Fragoso, E. N., J. E. Souza, M. R. Velludo, A. S. Soares, L. H. Silva, J. L. Rodrigues-Filho, N. Fenerich-Verani, J. R. Verani \& O. Rocha. 2005. Introdução de espécies e estado atual da ictiofauna da represa do Lobo, Brotas - Itirapina, SP. Pp. 47-58. In: Rocha, O. (Ed.). Espécies invasoras em águas doces - estudo de caso e propostas de manejo. São Carlos, Editora Universidade Federal de São Carlos, 416p.

Godinho, A. L., M. T. Fonseca \& L. M Araújo. 1994. The ecology of predator fish introductions: the case of Rio Doce Valley Lakes. Pp. 77-83. In: Pinto-Coelho, R.M., A. Giani \& E. Von Sperling (Eds.). Ecology and human impacts on lakes and reservoirs in Minas Gerais with special reference to future development and management strategies. Belo Horizonte, SEGRAC, 193p.

Gomiero, L. M. \& F. M. S. Braga. 2003. Relação peso-comprimento e fator de condição para Cichla ocellaris e Cichla monoculus (Perciformes, Cichlidae) no reservatório de Volta Grande, Rio Grande - MG/SP. Acta Scientiarum: Biological Sciences, 25(1): 79-86.

Gomiero, L. M. \& F. M. S. Braga. 2004. Reproduction of species of the genus Cichla in a reservoir in southeastern Brazil. Brazilian Journal of Biology, 64(3B): 613-624.

Hoeinghaus, D. J., K. O. Winemiller, C. A. Layman, D. A. Arrington \& D. B. Jepsen. 2006. Effects of seasonality and migratory prey on body condition of Cichla species in a tropical floodplain river. Journal of Freshwater Fish, 15: 398-407.

Honji, R. M., A. M. Vaz-dos-Santos \& C. L. D. B. RossiWongtschowski. 2006. Identification of the stages of ovary maturation of the Argentine hake Merluccius hubbisi Marini, 1933 (Teleostei: Merlucciidae): advantages and disadvantages of the use of the macroscopic and microscopic scales. Neotropical Ichthyology, 4(3): 329-337.

Jepsen, D. B., K. O. Winemiller, D. C. Taphorn \& D. Rodriguez Olarte. 1999. Age structure and growth of peacock cichlids of rivers and reservoirs of Venezuela. Journal of Fish Biology, 55: 433-450.
Kullander, S. O. \& E. J. G. Ferreira. 2006. A review of the South American cichlid genus Cichla with descriptions of nine new species (Teleostei: Cichlidae). Ichthyological Exploration of Freshwaters, 17(4): 289-398.

Le Cren, E. D. 1951. The length - weight relationship and seasonal cycle in gonad weight and condition factor in the perch (Perca fluviatilis). Journal of Animal Ecology, 20(2): 201-219.

Lowe-McConnell, R. H. L.1999. Estudos ecológicos de comunidades de peixes tropicais. São Paulo, EDUSP, 535p.

Magalhães, A. L. B., Y. Sato, E. Rizzo, R. M. A. Ferreira \& N. Bazzoli. 1996. Ciclo reprodutivo do tucunaré Cichla ocellaris (Schneider, 1801) na represa de Três Marias, MG. Arquivo Brasileiro de Medicina Veterinária e Zootecnia, 48(1): 85-92.

Marinelli, C. E. 2002. Introdução de espécies, Estrutura dos habitats e padrões de diversidade da ictiofauna em ecótonos do Reservatório do Broa, SP. Unpublished Master thesis, Universidade de São Paulo, São Carlos. 226p.

Nascimento, F. L., A. C. Catella \& A. S. Moraes. 2001. Distribuição espacial do tucunaré, Cichla sp (Pisces, Cichlidae), peixe amazônico introduzido no Pantanal, Brasil. Corumbá, Embrapa Pantanal, 17p.

Rocha, O., E. L. G. Espíndola, N. Fenerich-Verani, J. R. Verani \& A. C. Rietzler. 2005. O problema das invasões biológicas em águas doces. Pp. 9-12. In: Rocha, O. (Ed.). Espécies invasoras em águas doces - estudo de caso e propostas de manejo. São Carlos, Editora Universidade Federal de São Carlos, 416p.

Santos, E. P. 1978. Dinâmica de populações aplicada à pesca e piscicultura. São Paulo, Editora da Universidade de São Paulo, 129p.

Sato, Y. \& H. P. Godinho. 1988. A questão do tamanho de primeira maturação dos peixes de Três Marias, MG. Pp. 93-94. In: Associação Mineira de Aquicultura (Ed.). Coletânea de resumos dos encontros da Associação Mineira de Aquicultura (AMA): 1982-1987. Brasilia, CODEVASF, 137p.

Silva, J. X. \& M. J. L. Souza. 1987. Análise ambiental. Rio de Janeiro, Editora UFRJ, 196p.

Simberloff, D. 2003. Confronting introduced species: a form of xenophobia? Biological Invasions, 5: 179-192.

Smith, W., E. L. G. Espíndola \& O. Rocha. 2005. As introduções de espécies de peixes exóticas e aloctones em bacias hidrográficas brasileiras. Pp. 25-44. In: Rocha, O. (Ed.). Espécies invasoras em águas doces - estudo de caso e propostas de manejo. São Carlos, Editora Universidade Federal de São Carlos, 416p.

Souza, J. E., M. R. Velludo, E. N. Fragoso, L. M. Sabinson, N. Fenerich-Verani, J. R. Verani \& O. Rocha. 2005. Estrutura da população e aspectos reprodutivos de Cichla ocellaris Bloch \& Schneider, 1801 (Perciformes, Cichlidae) introduzido na represa do Lobo (Broa), estado de São Paulo. Pp. 59-71. In: Rocha, O. (Ed.). Espécies invasoras em águas doces - estudo de caso e propostas de manejo. São Carlos, Editora Universidade Federal de São Carlos, 416p.

Tundisi, L. G., T. Matsumura-Tundisi \& S. L. Rodrigues. 2003. Gerenciamento e recuperação das bacias hidrográficas dos rios Itaquerí e do Lobo e da UHE Carlos Botelho (Lobo-Broa). São Carlos, IIE/IIEGA, 72p.

Vazzoler, A. E. A. M. 1981. Manual de métodos para estudos biológicos de populações de peixes; reprodução e crescimento. Brasília, CNPq, 108p.

Vazzoler, A. E. A. M. 1996. Biologia da reprodução de peixes teleósteos: teoria e prática. Maringá, EDUEM; São Paulo, SBI, $169 \mathrm{p}$. 
Vieira, S. 1980. Introdução à Bioestatística 5ºd. revista e ampliada. Rio de Janeiro, Ed Campus Ltda, 196p.

Winemiller, K. O., D. C. Taphorn \& A. Barbarino-Duque. 1997. Ecology of Cichla (Cichlidae) in two blackwater rivers of Southern Venezuela. Copeia, 1997(4): 690-696.

Zar, J. H. 2001. Biostatistical analysis. Englewood Cliffs, PrenticeHall, 620 p.

Zaret, T. M. 1980. Life history and growth relationship of Cichla ocellaris, a predatory South American cichlid. Biotropica, 12: 144-157.

Zaret, T. M. \& R. T. Paine. 1973. Species introduction in a tropical lake. Science, 182: 449-455.

Accepted March 2008

Published June 28, 2008 